\title{
Cowden Syndrome - Diagnostic Skin Signs
}

\author{
C. Hildenbrand ${ }^{a}$ W.H.C. Burgdorf ${ }^{b}$ S. Lautenschlager ${ }^{a}$ \\ a Outpatient Clinic of Dermatology, Triemli Hospital, Zurich, Switzerland; b Department of Dermatology, \\ Ludwig Maximilian University, Munich, Germany
}

\section{Key Words}

Cowden syndrome . Cowden disease .

Multiple hamartoma syndrome

\begin{abstract}
Cowden syndrome is a rare autosomal dominant familial cancer syndrome with a high risk of breast cancer. The most important clinical features include carcinomas of the breast and thyroid, and hamartomatous polyps of the gastrointestinal tract. There are characteristic mucocutaneous features which allow early recognition of the disease and are generally present before internal malignancies develop. We report on a woman in whom the diagnosis of Cowden syndrome was first made after she had been treated for both breast cancer and melanoma.
\end{abstract}

Copyright $\odot 2001$ S. Karger AG, Basel

\section{Case Report}

A 64-year-old woman was referred to our outpatient clinic because of cosmetically disturbing facial papules. According to her history she had developed progressive symmetrical papules especially in the mid-face for more than 20 years. Twelve years ago a $\mathrm{CO}_{2}$ laser treatment had been performed elsewhere with only short-lasting cosmetic improvement. Her medical history included a mastectomy on the right side because of an infiltrating intraductal carcinoma in 1981, malignant melanoma in 1988 and intestinal bleeding of unknown etiology in 1992 and again in January 2000. Gynecological examination following postmenopausal bleeding in 1986 showed no relevant abnormalities.

There were no family members with similar conditions. The 92-year-old mother of the patient is apparently healthy. Her father died at 56 years of age but had no skin lesions. Her 39-year-old daughter has a history of fibrocystic disease of the breasts.

Physical examination disclosed multiple dome-shaped, skin-colored papules on the nose and in the nasolabial groove (fig. 1), some with a filiform appearance. Similar lesions were found periorally and in the retroauricular region (fig. 2). Many of these lesions were examined microscopically. They all showed follicular structures with prominent perifollicular fibrosis (fig. 3). Multiple papular lesions were also identified on the buccal and gingival mucosa creating a cobblestoned appearance (fig. 4). Additional findings included superficial keratoses on a slightly erythematous base on the right lateral ankle (fig. 5) and isolated small palmoplantar punctate keratodermas. Further examination by her gynecologist and family physician (including ultrasonography of the thyroid gland and of the abdomen) revealed no further abnormalities. Gastroscopy and colonoscopy were refused by the patient. Laboratory examinations (complete blood count, erythrocyte sedimentation rate, thyroid function tests, stool guaiac) were normal or negative.

Physical examination of her daughter revealed only tiny nasolabial papules $(1 \mathrm{~mm}$; fig. 6) without further signs of the disease.

\section{Discussion}

Cowden syndrome (CS), also known as Cowden disease or multiple hamartoma syndrome (MIM 158350), is a rare cancer-associated genodermatosis with an autosomal dominant pattern of inheritance and variable expressivity. This disease was initially described in 1963 by Lloyd and Dennis [1] and was named after their patient Rachel Cowden who died due to her breast cancer. Nine years later, Weary et al. [2] defined the syndrome as characterized by a variety of hamartomatous lesions with multiple organ system involvement, affecting tissues derived from ectodermal, endodermal and mesodermal tissue layers, with a slight female predominance.

Since then, over 150 cases of CS have been reported in the literature with the characteristic mucocutaneous features present in almost $100 \%$ of the cases, including warty facial papules (usually trichilemmomas), oral papillomatosis and acral keratoses [35]. Salem and Steck [6] proposed diagnostic criteria for multiple hamartoma syndrome which included major criteria (facial papules and oral papillomatosis), minor criteria (acral keratoses and palmoplantar keratoses) and family history. Diagnosis was considered definite in the presence of 2 major criteria, 1 major and 1 minor, 1 major and a positive family history, or 2 minor and a positive family history. Our patient had 2 major criteria and 2 minor criteria. Barax et al. [7] proposed inclusion of sclerotic fibromas, previously described in detail by Starink et al. [8], as an additional major criterion. In

\begin{tabular}{ll}
\hline KARGER & ( ) 2001 S. Karger AG, Basel \\
Fax +4161306 12 34 & 1018-8665/01/2024-0362\$17.50/0 \\
$\begin{array}{l}\text { E-Mail karger@karger.ch } \\
\text { www.karger.com }\end{array}$ & $\begin{array}{l}\text { Accessible online at: } \\
\text { www.karger.com/journals/drm }\end{array}$
\end{tabular}

Stephan Lautenschlager, MD

Outpatient Clinic of Dermatology, Triemli Hospital

Herman-Greulich-Strasse 70

CH-8004 Zurich (Switzerland)

Tel. +41 129889 00, Fax +41 129889 89, E-Mail stlauten@swissonline.ch 

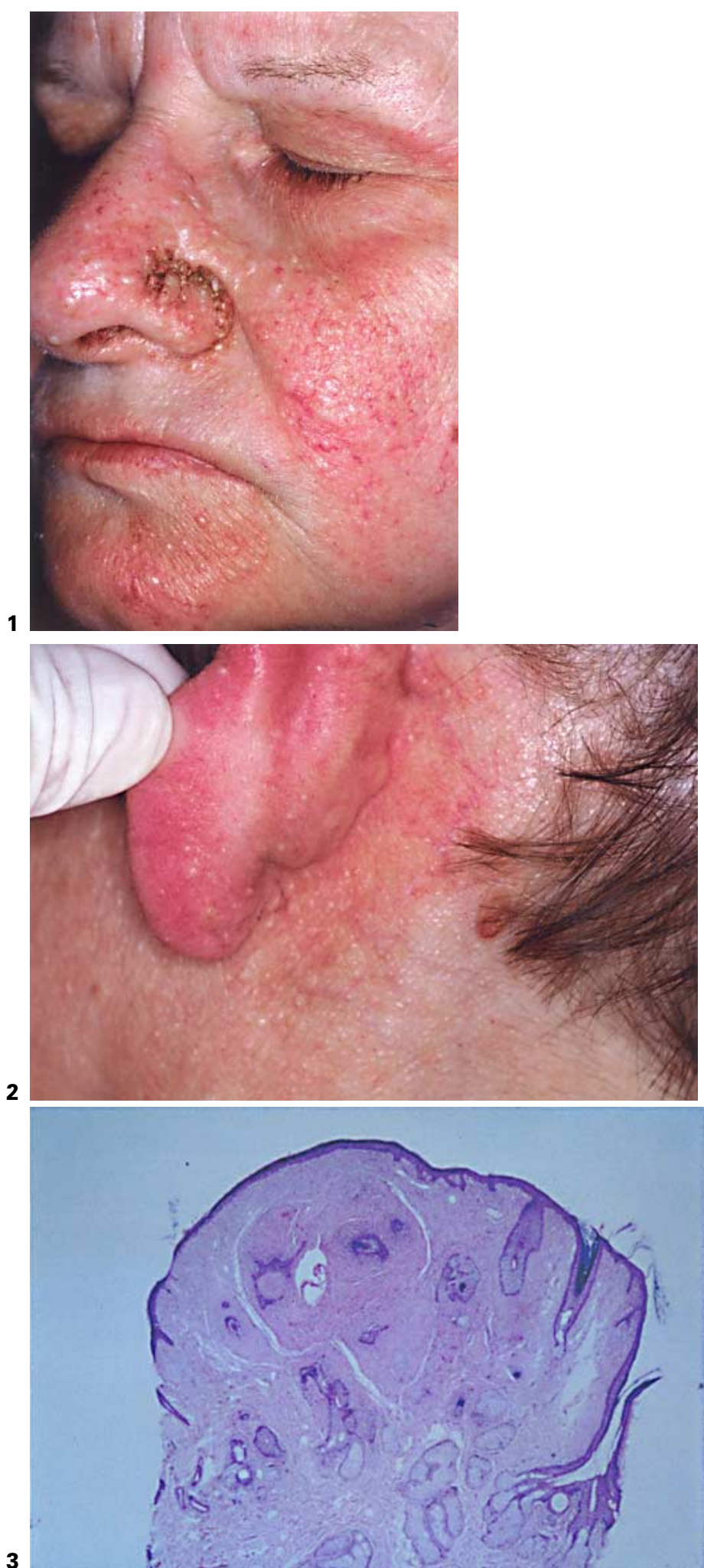
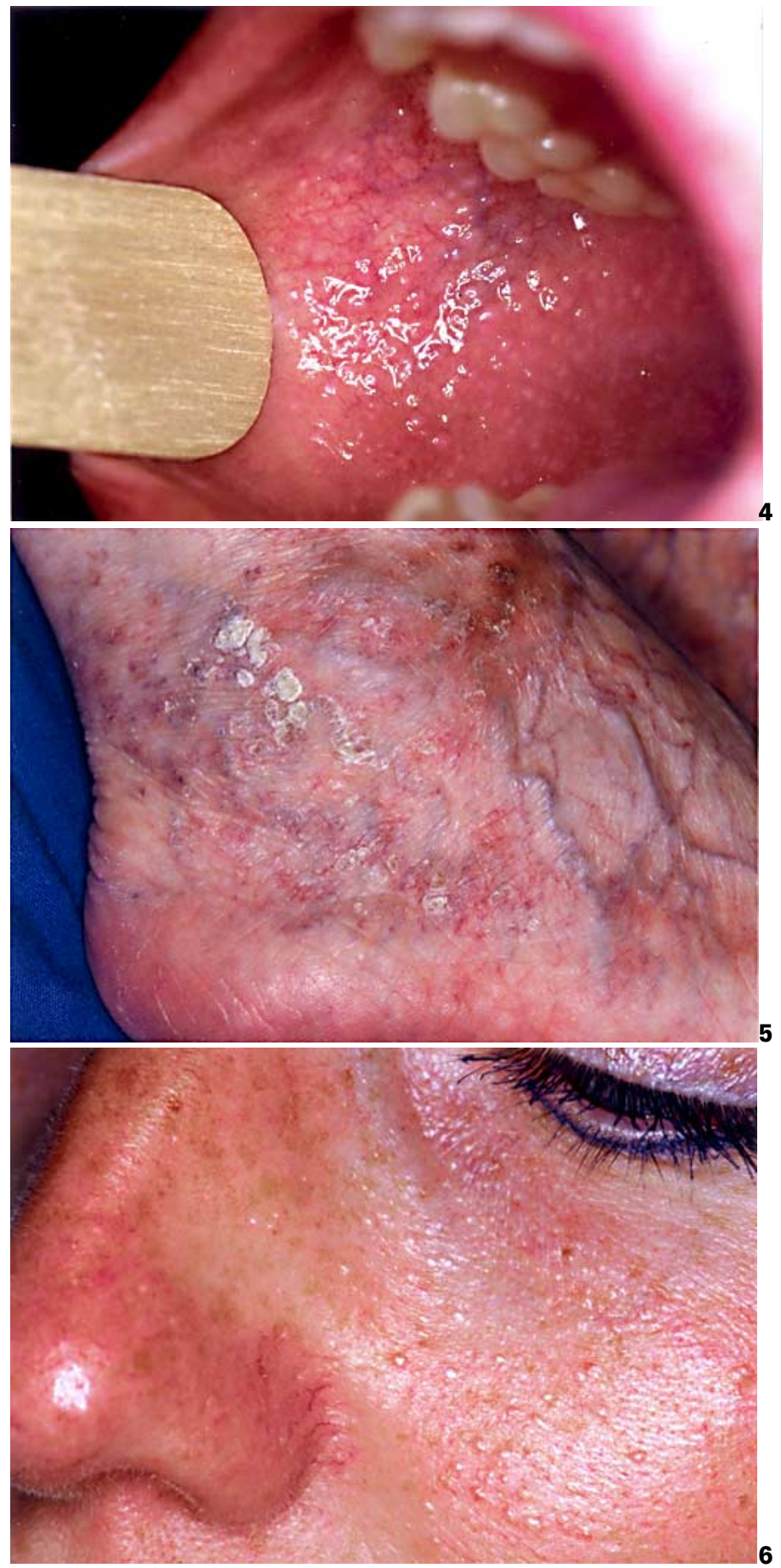

Fig. 1. Verrucous and dome-shaped papules on the nose and in the nasolabial groove.

Fig. 2. Grouped retroauricular papules.

Fig. 3. Histology of a nasal papule showing perifollicular fibroma.

Fig. 4. Closely set papules with a cobblestone pattern on the oral mucosa.

Fig. 5. Superficial keratoses on the right lateral ankle.

Fig. 6. The 39-year-old daughter of the patient showing tiny perinasal papules.

Dermatology 2001;202:362-366 
1998, the International Cowden Syndrome Consortium operational criteria delineated more detailed criteria for the diagnosis of CS (in Tsao [9]), which also included, among other diagnoses, breast cancer, thyroid cancer, macrocephaly and Lhermitte-Duclos disease (table 1).

Most often the characteristic skin signs develop in the 2nd and 3rd decades, but age at onset may vary from 4 to 75 years [10] in relation with the variability of the circumstances of discovery and the variability of expressivity. Our patient noticed the first papules after the age of 40 . Mucocutaneous findings are a prominent feature of the disease and present in every patient [4]. A detailed classification into 6 groups of skin lesions (lichenoid papules, acral keratoses, translucent keratoses of the palm, verrucous lesions, papillomatous lesions and mixed lesions) was made by Gianadda in her thesis [11]. Newer publications distinguish only between facial papules, acral keratoses, palmoplantar keratoses and mucocutaneous lesions according to Salem and Steck [6]. Facial papules are the most frequent lesions and can be found in up to $86 \%$ of cases [5], preferentially localized in periorificial regions, sometimes extending into the nostrils. Histologically, the lesions frequently show nonspecific hair follicle proliferations [12], as we found in our patient, or may reveal trichilemmomas. Acral verrucous hyperkeratosis on the extensor sides of the extremities and palmoplantar translucent keratoses are seen in about 28 and $20 \%$, respectively [4]. Involvement of the mucosa is very important for diagnosis and is present in over $80 \%$ $[4,12]$. Usually mucocutaneous lesions are present in multiple locations, particularly the buccal and gingival mucosa, where coalescent lesions lead to the characteristic cobblestone-like pattern [4] in $40 \%$ of patients, as in our case. Extension to the oropharynx, larynx, tongue and nasal mucosa may occur. Less often there may be anogenital involvement. Mucocutaneous lesions usually develop after facial lesions [10]. Further associated cutaneous findings include lipomas [7], hemangiomas [12], xanthomas [13], vitiligo [3, 13, 14], neuromas [7, 12], café au lait spots [15], periorificial and acral lentigines [16] and acanthosis nigricans [7].

Differential diagnosis of the cutaneous findings should include tuberous sclerosis, Gardner syndrome, epidermodysplasia verruciformis (Lewandowski-Lutz), Brooke syndrome, neurofibromatosis type 1 and multiple fibrofolliculomas (Birt-Hogg-Dubé syndrome). The biopsies from our patient's

Table 1. International Cowden Syndrome Consortium operational criteria for the diagnosis of CS

\begin{tabular}{|c|c|}
\hline $\begin{array}{l}\text { Pathognomonic criteria: } \\
\text { Mucocutaneous lesions }\end{array}$ & $\begin{array}{l}\text { Multiple facial trichilemmomas } \\
\text { Papillomatous papules } \\
\text { Mucosal lesions } \\
\text { Acral keratoses }\end{array}$ \\
\hline Major criteria & $\begin{array}{l}\text { Breast cancer } \\
\text { Thyroid cancer, especially follicular thyroid carcinoma } \\
\text { Macrocephaly } \\
\text { Hamartomatous outgrowths of cerebellum } \\
\text { (Lhermitte-Duclos disease) }\end{array}$ \\
\hline Minor criteria & $\begin{array}{l}\text { Thyroid lesions (e.g. adenoma or goiter) } \\
\text { Mental retardation (IQ } \leq 75 \text { ) } \\
\text { Hamartomatous intestinal polyps } \\
\text { Fibrocystic disease of the breast } \\
\text { Lipomas } \\
\text { Fibromas } \\
\text { Genitourinary tumors or malformations }\end{array}$ \\
\hline $\begin{array}{l}\text { Operational diagnosis } \\
\text { for individual }\end{array}$ & $\begin{array}{l}\text { (1) Mucocutaneous lesions alone if } \\
\text { (a) } \geq 6 \text { facial papules with } \geq 3 \text { trichilemmomas } \\
\text { (b) Cutaneous facial papules and oral mucosal papillomatosis } \\
\text { (c) Oral mucosal papillomatosis and acral keratoses } \\
\text { (d) } 6 \text { or more palmar/plantar keratoses } \\
\text { or } \\
\text { (2) } 2 \text { major criteria but one must include macrocephaly or } \\
\text { Lhermitte-Duclos disease } \\
\text { or } \\
\text { (3) } 1 \text { major and } 3 \text { minor criteria } \\
\text { or } \\
\text { (4) } 4 \text { minor criteria }\end{array}$ \\
\hline
\end{tabular}

facial papules more closely resembled fibrofolliculomas, as seen in Birt-Hogg-Dubé syndrome. Although we have never found a typical trichilemmoma in our patient, we are still confident she has CS. The nature of the follicular proliferations in many of the cancer-associated genodermatoses remains unclear and overlaps in histological pattern are not unusual. Birt-Hogg-Dubé patients have an increased risk of renal cell carcinoma [17] and do not have hyperkeratotic palmoplantar pits or cobblestoning of the oral mucosa [18].

Although nearly every internal malignancy has been reported in association with CS [9], breast cancer is most frequent occurring in approximately $22 \%$ of women [12]. The onset of breast cancer occurs at the same age as in patients without CS [12, 19]. Our patient was operated on for breast cancer at the age of 45 years and her daughter has a history of fibrocystic disease, which is seen concomitantly with carcinoma in $53 \%$ of female patients [3]. The importance of fibrocystic disease as a probable precursor lesion to incipient invasive carcinoma was stressed by Barax et al. [7]. The most frequently reported extracutaneous manifestation is thyroid disease, occurring in approximately two thirds of patients [3] including multinodular goiter, thyroidal dysfunction, thyroiditis and thyroid cancer [20], which represents the second most common associated carcinoma arising in 7\% [21].

Intestinal tract involvement with hamartomatous polyps is seen in $40-60 \%$ of patients $[10,12,22]$. This probably reflects an underestimation since intestinal lesions are often asymptomatic [10] and many reported cases have not had extensive gastrointestinal evaluation [7, 10]. A few cases of adenocarcinoma of the colon have been reported in patients with CS, but this association is usually considered to be coincidental because of the high frequency of colorectal cancer in the general population. Recently published cases suggest a possible relation to familial adenomatous polyposis and hereditary nonpolyposis colorectal cancer [23]. In 
our patient the source of intestinal bleeding could not be found by colonoscopy in 1992 . Malignant melanoma has been described in a few cases [24]. Associated extracutaneous manifestations and neoplasias are listed in table 2.

An autosomal dominant pattern of inheritance was first suggested by Weary et al. [2] and later confirmed by Starink et al. [12]. The apparently sporadic cases observed [6] probably represent de novo mutations. In 1996, the CS locus was mapped to human chromosome 10q22-23 by Nelen et al. [25]. Independently a mutated tumor suppressor gene PTEN (= phosphatase and tensin homolog deleted on chromosome 10, also called $M M A C 1$ ) was found at chromosome 10q23 in multiple solid advanced cancers $[26,27]$. Subsequently inactivating germline mutations of PTEN were found in patients with CS [28, 29]. A multitude of different $P T E N$ mutations in CS patients - scattered over the entire gene - have been reported [30]. Whether these genotypic differences cause phenotypic differences remains unclear. CS overlaps with several other hamartomatous syndromes. Lhermitte-Duclos disease, which is characterized by hamartomatous outgrowths of the cerebellum, was considered a distinct entity but is now considered a component of CS [31]. Recently mutations and deletions of PTEN have also been found in $38 \%$ of primary and in $58 \%$ of metastatic tumors, which may contribute to the development and progression of malignant melanoma [32]. Bannayan-Riley-Ruvalcaba syndrome (macrocephaly, vascular malformations, multiple lipomas, gastrointestinal polyps, thyroid disease and speckled penile pigmentation) exhibits a number of clinical similarities to CS [21,33], and recent studies have demonstrated that these 2 diseases are allelic disorders at the PTEN locus on chromosome 10q [21, 34]; however, Bannayan-Riley-Ruvalcaba syndrome lacks the high penetrance of cancer seen with CS.

Treatment of facial papules with topical 5-fluorouracil, oral retinoids, electrosurgery, cryosurgery, dermabrasion and laser ablation $[4,14,19,35]$ is often unsatisfactory and mostly with only temporary effects. There is no known therapy to actually prevent the development of carcinoma. Baseline studies should include thyroid function tests, thyroid scanning, complete blood count, urinalysis, mammography and chest radiography $[19,36]$. Due to the low potential for malignant degeneration of gastrointestinal polyps, screening in the absence of symptoms is not generally indicated [37].

Table 2. Benign and malignant extracutaneous manifestations in CS

\begin{tabular}{lll}
\hline & Malignant & Benign \\
\hline Breast & Breast carcinoma & Fibrocystic disease \\
& & Fibroadenomas \\
& Anatomical abnormalities \\
& Gynecomastia in males \\
\hline Thyroid gland & Thyroid carcinoma & Multinodular goiter \\
& & Adenoma \\
& Hyperthyroidism \\
& Hypothyroidism \\
& Thyroglossal duct cyst \\
& Thyroiditis
\end{tabular}

\begin{tabular}{lll}
\hline Gastrointestinal tract & Adenocarcinoma of the colon & Polyposis \\
& Hepatocellular carcinoma & Diverticula of colon and sigmoid \\
& & Ganglioneuromas \\
& Hepatic hamartomas
\end{tabular}

\begin{tabular}{lll}
\hline Urogenital system & Cervical cancer & Vulvar and vaginal cysts \\
& Adenocarcinoma of the uterus & Uterine leiomyomas \\
& Ovarian carcinoma & Ovarian cysts \\
Transitional carcinoma of the & Irregular menses \\
bladder & Hydrocele in males \\
& Varicocele in males \\
& Hypoplastic testes \\
\hline Eye & Cataracts \\
& Blood vessel anomalies \\
& Angioid streaks \\
& Myopia \\
\hline
\end{tabular}

\begin{tabular}{|c|c|c|}
\hline Nervous system & & $\begin{array}{l}\text { Neuromas } \\
\text { Neurofibromas } \\
\text { Meningiomas }\end{array}$ \\
\hline Skeletal & & $\begin{array}{l}\text { Adenoid facies } \\
\text { Bone cysts } \\
\text { Craniomegaly } \\
\text { High arched palate } \\
\text { Kyphoscoliosis } \\
\text { Pectus excavatum } \\
\text { Rudimentary sixth digit } \\
\text { Syndactylia }\end{array}$ \\
\hline Miscellaneous & $\begin{array}{l}\text { Acute myelogenous leukemia } \\
\text { Non-Hodgkin's lymphoma } \\
\text { Liposarcoma } \\
\text { Lung adenocarcinoma } \\
\text { Renal cell carcinoma }\end{array}$ & $\begin{array}{l}\text { Atrial septal defect } \\
\text { Pulmonary hamartomas } \\
\text { Mental retardation } \\
\text { Hypoplastic uvula }\end{array}$ \\
\hline
\end{tabular}

Further investigations by fine-needle aspiration, surgical biopsy or magnetic resonance imaging should be based on symptoms or abnormalities found in a thorough physical examination.

Cutaneous lesions are the most important markers for CS, since they are present in almost every patient and frequently appear prior to the development of any internal disease. Especially in the era of common laser treatments for cosmetic purposes, even in the absence of a clear diagnosis, dermatologists play an important role in making an early diagnosis which should lead to the earlier diagnosis and more effective treatment of the associated neoplasms. 
1 Lloyd KM, Dennis M: Cowden's disease: A possible new symptom complex with multiple system involvement. Ann Intern Med 1963;58: 136-142.

2 Weary PE, Gorlin RJ, Gentry WC Jr, Comer JE, Greer KE: Multiple hamartoma syndrome (Cowden's disease). Arch Dermatol 1972;106: 682-690.

3 Starink TM: Cowden's disease: Analysis of fourteen new cases. J Am Acad Dermatol 1984; 11:1127-1141.

4 Monnier G, Mauduit G, Thivolet J: La maladie de Cowden. Ann Dermatol Vénéréol 1985;112: 169-177.

5 Hanssen AM, Werquin H, Suys E, Fryns JP: Cowden syndrome: Report of a large family with macrocephaly and increased severity of signs in subsequent generations. Clin Genet 1993;44:281-286.

6 Salem OS, Steck WD: Cowden's disease (multiple hamartoma and neoplasia syndrome): A case report and review of the English literature. J Am Acad Dermatol 1983;8:686-696.

7 Barax CN, Lebwohl M, Phelps RG: Multiple hamartoma syndrome. J Am Acad Dermatol 1987;17:342-346.

8 Starink TM, Meijer CJ, Brownstein MH: The cutaneous pathology of Cowden's disease: New findings. J Cutan Pathol 1985;12:83-93.

9 Tsao H: Update on familial cancer syndromes and the skin. 2000;42:939-969.

10 Longy M, Lacombe D: Cowden disease: Report of a family and review. Ann Genet 1996;39: 35-42.

11 Gianadda E: Maladie de Cowden ou syndrome des hamartomes multiples: revue générale à propos d'un cas; thesis, Department of Dermatology, University of Lausanne, 1980, pp 1196.

12 Starink TM, van der Veen JP, Arwert F, de Waal LP, de Lange GG, Gille JJ, Eriksson AW: The Cowden syndrome: A clinical and genetic study in 21 patients. Clin Genet 1986;29:222233.

13 Wade TR, Kopf AW: Cowden's disease: A case report and review of the literature. J Dermatol Surg Oncol 1978;4:459-464.

14 Wheeland RG, McGillis ST: Cowden's disease - Treatment of cutaneous lesions using carbon dioxide laser vaporization: A comparison of conventional and superpulsed techniques. J Dermatol Surg Oncol 1989;15:1055-1059.
15 Nuss DD, Aeling JL, Clemons DE, Weber WN: Multiple hamartoma syndrome (Cowden's disease). Arch Dermatol 1978;114:743-746.

16 Koeppel MC, Lazzarini F, Lagrange B, Sayag J: Maladie de Cowden: polypes adénomateux. Lentiginose péri-orificielle. Ann Dermatol Vénéréol 1990;117:455-458.

17 Toro JR, Glenn G, Duray P, Darling T, Weirich G, Zbar B, Linehan M, Turner ML: BirtHogg-Dubé syndrome: A novel marker of kidney neoplasia. Arch Dermatol 1999;135:11951202.

18 Ubogy-Rainey Z, James W, Lupton G, Rodman O: Fibrofolliculomas, trichodiscomas, and acrochordons: The Birt-Hogg-Dubé syndrome. J Am Acad Dermatol 1987;16:452-457.

19 Mallory SB: Cowden syndrome (multiple hamartoma syndrome). Dermatol Clin 1995;13: 27-31.

20 Sogol PB, Sugawara M, Gordon HE, Shellow WV, Hernandez F, Hershman JM: Cowden's disease: Familial goiter and skin hamartomas. A report of three cases. West J Med 1983;139: 324-328.

21 Perriard J, Saurat JH, Harms M: An overlap of Cowden's disease and Bannayan-Riley-Ruvalcaba syndrome in the same family. J Am Acad Dermatol 2000;42:348-350.

22 Gorensek M, Matko I, Skralovnik A, Rode M, Satler J, Jutersek A: Disseminated hereditary gastrointestinal polyposis with orocutaneous hamartomatosis (Cowden's disease). Endoscopy $1984 ; 16: 59-63$.

23 Entius MM, Westerman AM, van Velthuysen ML, Wilson JH, Hamilton SR, Giardiello FM, Offerhaus GJ: Molecular and phenotypic markers of hamartomatous polyposis syndromes in the gastrointestinal tract. Hepatogastroenterology 1999;46:661-666.

24 Greene SL, Thomas JR III, Doyle JA: Cowden's disease with associated malignant melanoma. Int J Dermatol 1984;23:466-467.

25 Nelen MR, Padberg GW, Peeters EA, Lin AY, van den Helm B, Frants RR, Coulon V, Goldstein AM, van Reen MM, Easton DF, Eeles RA, Hodgsen S, Mulvihill JJ, Murday VA, Tucker MA, Mariman EC, Starink TM, Ponder BA, Ropers HH, Kremer H, Longy M, Eng C: Localization of the gene for Cowden disease to chromosome 10q22-23. Nat Genet 1996;13: 114-116.

26 Steck PA, Pershouse MA, Jasser SA, Yung WK, Lin H, Ligon AH, Langford LA, Baumgard ML, Hattier T, Davis T, Frye C, Hu R, Swedlund B, Teng DH, Tavtigian SV: Identification of a candidate tumour suppressor gene, MMAC1, at chromosome 10q23.3 that is mutated in multiple advanced cancers. Nat Genet 1997; 15:356-362.
27 Li J, Yen C, Liaw D, Podsypanina K, Bose S, Wang SI, Puc J, Miliaresis C, Rodgers L, McCombie R, Bigner SH, Giovanella BC, Ittmann M, Tycko B, Hibshoosh H, Wigler MH, Parsons R: PTEN, a putative protein tyrosine phosphatase gene mutated in human brain, breast, and prostate cancer. Science 1997;275: 1943-1947.

28 Liaw D, Marsh DJ, Li J, Dahia PL, Wang SI, Zheng Z, Bose S, Call KM, Tsou HC, Peacocke M, Eng C, Parsons R: Germline mutations of the PTEN gene in Cowden disease, an inherited breast and thyroid cancer syndrome. Nat Genet 1997;16:64-67.

29 Nelen MR, van Staveren WC, Peeters EA, Hassel MB, Gorlin RJ, Hamm H, Lindboe CF, Fryns JP, Sijmons RH, Woods DG, Mariman EC, Padberg GW, Kremer H: Germline mutations in the PTEN/MMAC1 gene in patients with Cowden disease. Hum Mol Genet 1997;6: 1383-1387.

30 Kubo Y, Urano Y, Hida Y, Ikeuchi T, Nomoto M, Kunitomo K, Arase S: A novel PTEN mutation in a Japanese patient with Cowden disease. Br J Dermatol 2000;142:1100-1105.

31 Padberg GW, Schot JD, Vielvoye GJ, Bots GT, de Beer FC: Lhermitte-Duclos disease and Cowden disease: A single phakomatosis. Ann Neurol 1991;29:517-523.

32 Birck A, Ahrenkiel V, Zeuthen J, Hou-Jensen K, Guldberg P: Mutation and allelic loss of the PTEN/MMAC1 gene in primary and metastatic melanoma biopsies. J Invest Dermatol 2000; 114:277-280.

33 Fargnoli MC, Orlow SJ, Semel-Concepcion J, Bolognia JL: Clinicopathologic findings in the Bannayan-Riley-Ruvalcaba syndrome. Arch Dermatol 1996;132:1214-1218.

34 Longy M, Coulon V, Duboue B, David A, Larregue $\mathrm{M}$, Eng $\mathrm{C}$, Amati $\mathrm{P}$, Kraimps JL, Bottani A, Lacombe D, Bonneau D: Mutations of PTEN in patients with Bannayan-Riley-Ruvalcaba phenotype. J Med Genet 1998;35:886889.

35 Cnudde F, Boulard F, Muller P, Chevallier J, Teron-Abou B: Maladie de Cowden: traitement par acitrétine. Ann Dermatol Vénéréol 1996;123:739-741.

36 Krasovec M, Elsner P, Burg G: Cowden-Syndrom. Hautarzt 1995;46:472-476.

37 Taylor AJ, Dodds WJ, Stewart ET: Alimentary tract lesions in Cowden's disease. Br J Radiol 1989;62:890-892. 